\title{
POMIĘDZY BRAZYLIJSKOŚCIĄ A EUROPEJSKOŚCIĄ. PYTANIA O REALIZACJE EDUKACJI MIĘDZYKULTUROWEJ - JAKOŚCIOWE STUDIUM PRZYPADKU
}

\section{BEING IN-BETWEEN BRASILIAN AND EUROPEAN. QUESTIONS CONCERNING INTERCULTURAL EDUCATION - CASE STUDY RESEARCH}

\author{
Anna Maria Jeznach ${ }^{1(\mathrm{~A}, \mathrm{~B}, \mathrm{C}, \mathrm{D}, \mathrm{E}, \mathrm{F})}$, Marzena Ruszkowska ${ }^{2(\mathrm{~A}, \mathrm{C}, \mathrm{D}, \mathrm{E}, \mathrm{F})}$
}

${ }^{1}$ Collegium Mazovia Innowacyjna Szkoła Wyższa w Siedlcach, Wydział Nauk o Zdrowiu, Katedra Pielęgniarstwa ${ }^{2}$ Państwowa Szkoła Wyższa im. Papieża Jana Pawła II w Białej Podlaskiej, Wydział Nauk o Zdrowiu i Nauk Społecznych

Jeznach, A.M, Ruszkowska, M. (2018). Pomiędzy brazylijskością a europejskością. Pytania o realizację edukacji międzykulturowej - jakościowe studium przypadku. Rozprawy Społeczne, 12(1), 40-49. https://doi.org/10.29316/rs.2018.05

Wkład autorów:

A. Zaplanowanie badań

B. Zebranie danych

C. Dane - analiza i statystyki

D. Interpretacja danych

E. Przygotowanie artykułu

F. Wyszukiwanie i analiza

literatury

G. Zebranie funduszy

Tabele: 43

Ryciny: 0

Literatura: 39

Otrzymano: marzec 2017

Zaakceptowano: maj 2017

\begin{abstract}
Streszczenie
Artykuł zawiera analizę i interpretację indywidualnych przeżyć, doświadczeń, poglądów, wartości przedstawiciela innej kultury, będącego w trakcie kształtowania własnej tożsamości. Dobór przypadku był celowy, zorientowany na uzyskanie informacji. Metodą badawczą było jakościowe studium przypadku. Zastosowano techniki badawcze: wywiad narracyjny (przeprowadzono analizę zorientowaną na znaczenie z kodowaniem), skalę do badania tożsamości etnicznej (Phinney, 1992) skalę trudności doświadczanych w obcej kulturze (Furnham, Bohner, 1986). Wyniki dotyczą wymiarów wielowymiarowej tożsamości badanego przypadku z uporządkowanymi 20 kategoriami pojęciowymi i ich kodami oraz interpretacją znaczeń nadawanych wymiarom tożsamości narratora. Raport przedstawia znaczenie poznawcze i praktyczne badanego przypadku. W tekście znajduje się odniesienie do kategorii tożsamości: Skarga, 1997; Borowik, Leszczyńska, 2007; Nikitorowicz, 2015; Sokolik, 1992; Kubacka-Jasiecka, Kuleta, 2008, Giddens, 2001 Suchocka, Królikowka, 2014; odniesienie do teorii zachowań tożsamościowych: Ogrodzka-Mazur, 2014, Gajdzica, 2013, Grabowska, 2013, Kurzępa, 2007, Misiejuk, 2013, Ogrodzka-Mazur, 2007, Sobecki, 2007, Szczurek-Boruta, 2007, Urlińska; Wojakowski, 2007,0grodzka-Mazur, 2014; odniesienie do badań profili tożsamościowych: Ogrodzka-Mazur, 2014; odniesienie do jakościowych badań tożsamości: Gurwitsch 1966 za: Moustakas, 2001.
\end{abstract}

Słowa kluczowe: edukacja międzykulturowa, jakościowe studium przypadku, wielowymiarowa tożsamość

\section{Summary}

The article contains analysis and interprets an individual experience, feelings, perspectives and value system of a man (the representative of another culture) who is on his way to shape his own identity. The research method that enabled reaching the aim was the qualitative research study in which four research techniques were applied, i.e. a narrative interview (the analysis oriented on the meaning of coding), a scale researching ethnical identity (Phinney, 1992), a range of hardships experienced in an alien culture (Furnham, Bohner, 1986). The selection of the case was determined by a wish to gain information. The results concern the dimensions of multidimensional identity tested with 20 conceptual categories, as well as the codes and interpretation of the meanings of broadcast dimensions of the identity of the narrator. The report presents the cognitive and practical significance of the case. The text makes references to the following - category of identity, Complaints, 1997; Borowik, Leszczyńska, 2007; Nikitorowicz, 2015; Sokolik, 1992; references to the theory of identity behaviour: OgrodzkaMazur, 2014, Gajdzica, 2013, Grabowska, 2013, Kurzępa, 2007, Misiejuk, 2013, Ogrodzka-Mazur, 2007, Sobecki, 2007, Szczurek-Boruta, 2007, Urlińska; Wojakowski, 2007, Ogrodzka-Mazur, 2014; reference to research on identity profiles: Ogrodzka-Mazur, 2014; reference to qualitative analysis of identity: Gurwitsch 1966, Moustakas, 2001.

Keywords: intercultural education, multidimensional identity, case study research

Tożsamość jednostki kształtuje się w konkretnej grupie, pod wpływem określonej kultury. Człowiek nie ma innej możliwości tworzenia siebie, koncepcji siebie czy identyfikowania się (przynależności) z kimś, jeśli nie znalazł grupy odniesienia...

Adres korespondencyjny: Anna Maria Jeznach, Collegium Mazovia Innowacyjna Szkoła Wyższa w Siedlcach, ul. Sokołowska 161, 08-110 Siedlce, e-mail: ajeznach@mazovia.edu.pl, tel.: 48256333032

Copyright by: Państwowa Szkoła Wyższa im. Papieża Jana Pawła II w Białej Podlaskiej, Anna Maria Jeznach, Marzena Ruszkowska

Czasopismo Open Access, wszystkie artykuły udostępniane są na mocy licencji Creative Commons Uznanie autorstwa-użycie niekomercyjne-na tych samych warunkach 4.0 Międzynarodowe (CC BY-NC-SA 4.0, http://creativecommons.org/licenses/by-nc-sa/4.0/). 
Prezentowany przypadek jest interesujący sam w sobie (charakter autoteliczny) (Stake, 2009, s. 627), ale również przedstawia szerszy kontekst: trudnego i złożonego procesu kształtowania się toźsamości (...) (Nikitorowicz, 2015, s. 125-134) (charakter instrumentalny) (Stake, 2015, s. 628). Zainteresowania badawcze koncentrują się na wybranych sferach codziennego świata życia (Kvale, 2012, s. 42) młodego człowieka, narodowości brazylijskiej, absolwenta polskiej uczelni. Cel badań dotyczy poznania przeżyć, jednostkowych doświadczeń, poglądów, systemu wartości badanego przypadku. Stosując metodę jakościowego studium przypadku (Yin, 2015), stawiamy pytania dotyczące realizacji edukacji międzykulturowej.

Przyjmujemy, że rzeczywistość społeczna, w jakiej funkcjonował student (później absolwent polskiej uczelni) narodowości brazylijskiej wyłania się z interakcji (Hałas, 1983, s. 35), dlatego za teoretyczną podstawą badań uznajemy paradygmat społecznej definicji (Grey, 2005, za: Gwiazda, 2010, s. 23), nazywany podejściem idiograficznym (Malim, Birch, Wadeley, 1994, s. 78-84) lub interpretacyjnym (Łuszczak, 2011). Realizując cel i poszukując kategorii pozwalającej opisać sposób doświadczania i zachowania młodego człowieka, odnosimy się do teorii zachowań tożsamościowych T. Lewowickiego (Lewowicki, 1995, s. 13-27). Wprowadza on kategorię tożsamości wielowymiarowej, która: łączy identyfikację lokalną, regionalną, państwową i europejskq z różnymi powiązaniami narodowościowymi, etnicznymi, religijnymi, wyznaniowymi, kulturowymi. Poszczególne składniki tej wielowymiarowej tożsamości bywaja wybierane przez ludzi - zgodnie z ich przekonaniami, poglądami, wierzeniami, a także dziedzictwem kulturowym. Ten typ tożsamości ma charakter otwarty - nie zależy od „dziedziczonej” narodowości, koloru skóry czy religii (Lewowicki, 2010, s. 492-493).

Przyjmujemy także, że: edukacja międzykulturowa wymaga wysiłku, wyjścia naprzeciw drugiej kulturze (Nikitorowicz, 1995), oraz, że jest to: (...) ogół wzajemnych wpływów i oddziaływań jednostek i grup, instytucji, organizacji, stowarzyszeń, związków, sprzyjających takiemu rozwojowi człowieka, aby stawał się on w pełni świadomym i twórczym członkiem wspólnoty rodzinnej, regionalnej, wyznaniowej, narodowej, kontynentalnej, kulturowej i globalnej - planetarnej oraz był zdolny do aktywnej samorealizacji własnej, niepowtarzalnej i trwałej toźsamości i odrębności (Nikitorowicz, 2003). Takie rozumienie edukacji międzykulturowej umożliwia postawienie pytań skłaniających do refleksji nad realizacją działań edukacyjnych w Polsce.

Biorąc pod uwagę cel i ramy teoretyczne, za nadrzędny problem badawczy uznajemy pytanie o profile identyfikacji tożsamościowej absolwenta polskiej uczelni narodowości brazylijskiej. Nadajemy szczegółowym problemom badawczym postać konstruktów (Schütz, 2008, s. 137-191).

Konstrukty I stop. (Schütz, 2008, s. 136): Jakie doświadczenia stały się udziałem absolwenta polskiej uczelni narodowości brazylijskiej w procesie kształtowania jego tożsamości?

1. Jak charakteryzuje On swoją sytuację życiową? 1.1. Jakie są motywy Jego działań życiowych?
1.2. Na jakie dylematy w obecnej sytuacji życiowej zwraca On uwagę?

1.3. Jakie przekonania posiada On o swojej sytuacji życiowej i rzeczywistości społecznej?

Konstrukty II stop. (Schütz, 2008, s. 152).

W jaki sposób można zinterpretować znaczenia nadawane wymiarom tożsamości przez absolwenta polskiej uczelni narodowości brazylijskiej?

1. Jakie znaczenie nadaje On wymiarowi lokalnemu własnej tożsamości?

2. Jakie znaczenie nadaje On wymiarowi regionalnemu własnej tożsamości?

3. Jakie znaczenie nadaje On wymiarowi państwowemu własnej tożsamości?

4. Jakie znaczenie nadaje On wymiarowi europejskiemu własnej tożsamości?

\section{Pojęcia porządkujące: brazylijskość; europejskość}

Termin brazylijskość jest trudny do zdefiniowana biorąc pod uwagę: źródła procesów społeczno - historycznych Brazylii (Malinowski, 2013, s. 7). Ludność Brazylii: (...) jest niezwykle heterogeniczna. Obecne społeczeństwo tworza potomkowie ludności autochtonicznej, portugalskich kolonizatorów, niewolników z Afryki oraz osadników z Europy i Azji (...). Zjawiskiem historycznym jest imigracja: dobrowolna i przymusowa, która stanowi podstawę: złożonej tożsamości Brazylijczyków (Malinowski, 2013, s. 8). Wiele różnic rasowych, językowych, religijnych, kulturowych stanowi pewną trudność $\mathrm{w}$ definiowaniu i nabywaniu tożsamości narodowościowej (Malinowski, 2013, s. 12) oraz trudność w nabyciu poczucia ważności narodu. Dlatego w literaturze przedmiotu przy definiowaniu terminu brazylijskość pojawia się określenie tożsamości zbiorowej z opisem specyfiki brazylijskiej tradycji kulturowej (Malinowski, 2011). Latynoamerykanista podkreśla, że brazylijskość istnieje zawsze: między pamięcią historyczna a projektem narodowym, tzn. pomiędzy odkrywaniem a aktem kreacji, między silnym poczuciem tożsamości narodowej a brazylijskością traktowaną jako: otwarta przestrzeń interpretacji (Malinowski, 2011, s. 398).

Główne cechy narodowe charakteru brazylijskiego to: serdeczność (Buarque de Holand, 1936) (najtrwalszy i najsilniej zakorzeniony w brazylijskiej mentalności wzór zachowania i postrzegania świata), polegającą na: dominacji zachowań afektywnych, przedkładaniu więzi pokrewieństwa i zwiq̨zków prywatnych nad działania $w$ imię interesu ogółu, (...) niezdolności do odrzucenia wartości rodzinnych i przenoszenia ich na sferę życia publicznego. Za przejaw serdeczności należy uznać kierowanie się sercem: $w$ sprawach prywatnych, jak i służbowych (...) nie znosza podporzadkowania ani dyscypliny (Malinowski, 2008, s. 18-38).

Literatura przedmiotu podaje, że unikalną cechą mentalności brazylijskiej jest tęsknota, saudate (stan ducha, składnik obyczajowości, jeden z filarów tożsamości). Według M. Malinowskiego nie jest czymś utraconym, ale przekazywanym z pokolenia na pokolenie, elementem kultury (Malinowski, 2008). Pozostałe ważne cechy Brazylijczyków, według felietonisty 
P. M. Camposa, to umiejętność kombinowania (jeitinho, sposobik) - powszechnie akceptowane, a nawet pożądane działanie, opierające się na improwizacji, kreatywności, pozwalające na swobodną interpretację formalnych zasad, nie łamiąc prawa i umiejętność odkładania na później (Bąk, 2015). Podkreśla się silniejsze poczucie przynależności regionalnej niż narodowościowej Brazylijczyków.

Europejskość natomiast można interpretować w różny sposób, przyjmując np. kryteria: granice geograficzne, uwarunkowania historyczne, wspólnotę aksjologiczną czy kulturową. W szerokim rozumieniu pojęciem tym określa się jedność cywilizacyjno-kulturową Europy opartą na filarach: kulturze helleńskiej, instytucjach politycznych i prawnych wynikających z doktryn prawników rzymskich, wartościach etycznych wypływających z religii chrześcijańskich, renesansowej antropologii i teorii państwa oraz racjonalizmu oświeceniowego (Bokajło, 2009, s. 28). Europejskość jako synonim tożsamości kulturowej Europy to zespół różnorakiego dziedzictwa odnoszącego się do postaw i stylów życia, ideałów historycznie ukształtowanych i znamiennych dla tego kontynentu. To swoista jedność w różnorodności, trudna do jednoznacznego określenia, niemniej jednak pozwalająca na postrzeganie edukacji w szerszym kontekście człowieczeństwa (humanitas), realizowanie zasady wolności i demokracji, umiejętności współistnienia i współpracy mimo różnic narodowych, religijnych, gospodarczych (Gajda, 2003, s. 38-49). Można wyróżnić trzy wymiary pojęcia europejskości:

- skala form przejawu europejskości (realnego istnienia - miejsce zamieszkania, fizyczno-fizjologiczne cechy, tryb i poziom życia vs. wirtualnego bytowania - hierarchia wartości, historia, tradycje, osiągnięcia informacyjne)

- skala źródeł europejskości (tradycyjno-historyczne vs. intencjonalno - przyszłościowe)

- $\quad$ skala funkcji cywilizacyjno-kulturowych (wartości ekonomiczno-poznawcze, racjonalne vs. wartości etyczno - estetyczne, emocjonalne) (Leszczak, 2009). Europeizacja obejmuje nie tylko instytucje, obszary polityki, ale ma wpływ na wymiar socjalizacyjny, na identyfikacje tożsamościowe Europejczyków.

\section{Materiał i metody}

Osoba badana - podmiotem badania był przedstawiciel innej kultury (Kvale, 2012, s. 120). Metodą badawczą było jakościowe studium przypadku (Flyvbejerg, 2005).

Techniki badawcze - zbadano tożsamość etniczną skalą The Multigrup Ethnic Measure (MEIN) (Phinney, 1992). Materiał badawczy uzyskano również stosując Skalę trudności doświadczanych w obcej kulturze (Furnham, Bochner, 1986, s. 564). Przeprowadzono 5 wywiadów narracyjnych (Kvale, 2012, s. 127-129; Chase, 2009, s. 15-55; Jacob, 2001, s. 111-126).

Procedura badania - wykonano jakościową analize zorientowaną na znaczenie z kodowaniem (Kvale, 2012, s. 170-171). Dokonano interpretacji (Szachaj, 2014), znaczeń nadawanych przez narratora z podejściem skupionym na pracy z tożsamościq̨ (Chase, 2009, s. 28).

\section{Wyniki}

Opis przypadku (Flyvbejerg, 2005, s. 53), W1, s. 1,2,121; W3, s. 8; W5, s. 1,5

- płeć: M; wiek: 26 lat; narodowość: brazylijska; stan cywilny: kawaler; wykształcenie: licencjat z turystyki: spec. hotelarstwo: uzyskany na polskiej, publicznej uczelni; kurs jęz. polskiego i barmana; miejsce pobytu: Warszawa, Lublin, Poznań: Polska; Serra - w stanie Espírito Santo: Brazylia; znajomość jęz.: hiszpański, angielski, francuski, polski, portugalski; pochodzenie społeczne: matka Sonia, nauczycielka francuskiego w szkole podstawowej, ojciec Joel - kierownicze stanowisko w firmie wodociągowej; struktura rodziny: 2 siostry, matka, ojciec.

- Tożsamość etniczna wg MEIN (Phinney, 1992): komponent poznawczy (na 5 pytań - 3x zgadzał się, $1 \mathrm{x}$ bardzo się zgadzał, $1 \mathrm{x}$ nie zgadzał się); komponent afektywny (na 6 pytań - 4 zgadzał się, 2 - nie zgadzał się); identyfikacja, kategoryzacja etniczna: etniczność określił jako: Hispanic Or Latino, including Mexican American, Central American, and others: Mixed, Parents are from two different groups.

$\checkmark \quad$ My father's ethnicity is: Hispanic or Latino; My mother's ethnicity is White, Coucasian (Phinney, 1992).

- Trudności doświadczane w obcej kulturze (Boski, 2010): na 40 sytuacji, tylko 6 - jest bardzo trudna dla badanego, 17 - nieco trudna, 14 - jest dość łatwych i 3 - bardzo łatwe.

\section{Kategoria wielowymiarowej tożsamości badanego przypadku}

Pojęcie tożsamość rozumiemy jako: twórczy wysiłek podmiotu łagodzacy napięcia i sprzeczności pomiędzy elementami stałymi, odziedziczonymi, wynikajacymi z zakorzenienia społecznego $w$ rodzinie $i$ społeczności lokalnej, identyfikacji z osobami znaczącymi, symbolami i wartościami rdzennymi a elementami zmiennymi, nabywanymi i wynikajacymi $z$ interakcji $z$ innymi (Nikitorowicz, 2015, s. 125-135). Kształtowanie się tożsamości traktujemy jako proces dynamiczny i zmienny (Nikitorowicz, 2015), (Jeznach, 2011, s. 169-187; 2016).

Wywiady narracyjne uznajemy za narracje osobiste (Chase, 2009, s. 18). Natomiast narrację jako: retrospektywne nadawanie znaczenia; jako: specyficzna i niepowtarzalna, a siebie postrzegamy jako narratorów. Interpretujemy znaczenia nadawane przez badanego (Chase, 2009, s. 24-26). Przedstawiamy 20 wyłonionych kategorii o charakterze analitycznym i teoretycznym, ich kody uporzadkowane w wymiary tożsamości narratora oraz interpretacje $^{2}$.

W- oznacza nr wywiadu

Ramy tekstu nie pozwalają na umieszczenie pozostałych analiz i interpretacji dotyczących, m.in.: własnej osoby (np. religii); Polski i Polaków, Brazylii i Brazylijczyków, edukacji, kobiet, odrębności 
Wymiar rodzinno-lokalny wielowymiarowej tożsamości absolwenta polskiej uczelni narodowości brazylijskiej

Kategoria nadrzędna: identyfikacja rodzinna; kategoria podrzędna: świat dzieciństwa; kody: zabawa; radość; technologia

Tabela 1

Narracja 1 W2, s. 1

Był duży babelkowy, był kolory, miałem radość, cieszy$\nmid$ łem się, tak czułem fajne, teraz nic nie sprawia jakoś radość, za duży tych technologii, ludzi nie sq jak kiedyś

Kategoria nadrzędna: poczucie przynależności do rodziny; kod: więź z rodziną

Tabela 2

Narracja 2 W3, s. 2

Najbardziej czuję się zwiqzany z rodzina, jedyni ludzie, które mogę zaufać i liczyć na nich, całkiem

Interpretacja: Narrator czuje najsilniejszą więź z rodziną, pomija kolegów, społeczność lokalną, naród, przyjaciół. Podstawą relacji jest dla niego zaufanie.

Kategoria podrzędna: tęsknota rodziców; kody: walka; rozwój; zmiana

Tabela 3

Narracja 3 W3, s. 10

Oni tęsknia, chca żebym wrócił, nie cierpiał dalej, a ja chciałbym dalej walczył i dalej wygrał wszystko

Interpretacja: Narrator wyraża chęć walki, rozwoju, zmiany, szukania, kształtowania tożsamości.

Kategoria nadrzędna: identyfikacji lokalna tożsamości; kategoria podrzędna: przekaz tradycji

kody: dialekt; kuchnia; miłość

Tabela 4

Narracja 4 W1, s. 1

Każdy ma swój dialekt, kuchnia, swoje wszystko, miłość, w innych miastach już inny

Kategoria podrzędna: poczucie związku z miejscem zamieszkania; kody: lokalny patriotyzm; tożsamość lokalna

Tabela 5

Narracja 5 W1, s. 1

Bardzo podoba mi się u mnie mieszkać, moje miasto jest jedno z najbardziej teraz, które się szybko rozwija, każdy lokal tam u nas ma, każdy ma tożsamość

Badany nadaje duże znaczenie poczuciu tożsamości rodzinno - lokalnej. Wyraża to $\mathrm{w}$ silnym poczuciu związku z rodziną, więzi z rodzinnym miejscem zamieszkania, lokalną tradycją, świadomością tęsknoty bliskich.
Wymiar regionalny wielowymiarowej tożsamości badanego

Kategoria nadrzędna: identyfikacja regionalna; kategoria podrzędna: poczucie wspólnoty regionalnej; kod: postawa życiowa

\section{Tabela 6}

Narracja 6 W1, s. 2; W1, s. 7

$W$ regionie łacińskim mamy podejście do życia inne niż $w$ Europie. Tradycjonalne miasto $w$ moim kraju, to sa stolica Brazylia, Rijo, San Paulo, Kurytyba, Portła Degre, były zawsze historyczne najbardziej silny ekonomicznie, większość tych Portugalczyków, Włochów, Hiszpanów jest też duża Polaków w Brazylii do $3 \mathrm{mln}$ z pochodzenia Polski, przyjechali razem z Niemców, to jest z emigracja duża 1900 r. Miksowanie kultury, kuchni, wszystkiego, tak jak w garnku różne rzeczy i na koniec takie coś, które nazywasz po prostu, już masz Brazylijska, która się skoncentrowała $z$ różnych narodowość

Interpretacja: Narrator ma świadomość, że na tożsamość brazylijską składają się elementy różnych kultur, narodowości. To one wg. badanego tworzą tożsamość brazylijską.

kod: ważne święta regionalne

\section{Tabela 7}

Narracja 7 W3, s. 3

Tak samo jak tutaj, spotykają się, spędzq dzień razem i później do kościoła, prezenty, modlitwa

Narrator wyraża poczucie związku z tradycja, mówi o rytuałach związanych z religią, dających ludziom poczucie przynależności.

kod: atmosfera regionu

\section{Tabela 8}

Narracja 8 W4, s. 3

Poczucie bliskości: klimat, inny wygląd ludzi i architektury, wygląd tzn. architektura, miasto, uroda ludzi Wypowiedź narratora świadczy o tym, że jest wzrokowcem, tzn. to, co widzi działa na Jego emocje, wzbudza zachwyt, podziw - jak u dziecka, które cieszy się z błyskotek. Możliwe, że podziw dla zewnętrznych elementów daje mu poczucie przynależności z regionem.

Narrator nadaje duże znaczenie tożsamości regionalnej. Wyraża się to jednak w zachwycie nad zewnętrznymi przejawami regionalności.

\section{Wymiar państwowy wielowymiarowej tożsamości badanego}

Kategoria nadrzędna: identyfikacja państwowa; kategoria podrzędna: samookreślenie państwowości; kod: język

\section{Tabela 9}

Narracja 9 W4, s. 3

język: pochodzacy z łaciny

kod: ważne święta państwowe 


\section{Tabela 10}

Narracja 10 W3, s. 3

Między marc i kwiecień jest taki karnawał $w$ każdy dużym miasto, tutaj też jest karnawat, ale to nie tak samo. Niedługo będzie też drugi karnawał, który określa bardziej nasze miejscowości nazywa FORTAL a to jest taki karnawał od 100 lat i taki specyficzny nasze region i sq bardziej, $w$ tym okresie jak jestem w Polsce. Ja nie czuję tego tak jak tam. Też Boże Narodzenie, nie mamy tak samo potrawy jak $w$ Polsce, tutaj bardziej Narrator dostrzega znaczącą różnicę między karnawałem w Polsce i w Brazylii. Prawdopodobnie w Brazylii ludzie więcej się bawią, są radośniejsi, bardziej otwarci niż w Polsce.

kod: mix kultur

\section{Tabela 11}

Narracja 11 W1, s. 7

nasz kraj jak USA, skoncentrował na emigracja, kolejne emigracja, i miksowanie kultury

kod: zaniedbanie

\section{Tabela 12}

\section{Narracja 12 W5, s. 5}

Zostało we mnie coś typowo brazylijskie, tako jak by nie za dużo myśleć żyć a w Polsce tak nie ma, nie za dużo myślisz i żyć to znajdziesz już poza tematem, trzeba tutaj właśnie myśleć i głębokie myśleć, ja nie zachowałem np. dystansu, ja zawsze byłem bliski do ludzi i opowiadam wszystko i przez to przyszli do mnie wtedy policja Narrator z jednej strony przejawia otwartość, ufność, spontaniczność, z drugiej nie posiada komponentu dojrzałego, który nie działa jedynie emocjonalnie, ale również racjonalnie.

kod: zmiana osobowości

\section{Tabela 13}

Narracja 13 W5, s. 5

Ja tylko gadam o zmiana, ale faktycznie, głębokie się nie zmieniłem, uważam, że trudno dla mnie zmienić całkiem, trudno ze względu, że ja miałem kłopoty żeby zmienić się na osobe, która dostosuje sie całkiem do kultura Polska i przez to dostałem wyjazd, bo nie szanowałem do końca życia Polski, jeśli chodzi o przepisy, pracę Zmiana osobowości narratora nastąpi po zderzeniu z inną kulturą, jako późniejszy skutek nabywania poczucia własnej tożsamości, poprzez porównanie z Polakami.

kod: zachowania

\section{Tabela 14}

\section{Narracja 14 W4, s. 1}

Patrzenie komuś w oczy, to jest znak szczerości, chyba wszędzie to jest? Prawdopodobnie to przejaw powierzchowności narratora, raczej wiedza o emocjach a nie uwewnętrznienie emocjonalne.

kod: święta religijno-państwowe

\section{Tabela 15}

Narracja 15 W3, s. 3

Tęsknię za Bożym Narodzeniem

Narrator tęskni, ponieważ towarzyszą jemu emocje dziecka za prezentami, za rodziną, za dopieszczeniem.

kod: zainteresowanie krajem

\section{Tabela 16}

Narracja 16 W3, s. 6

Codziennie wejdę i czytam wiadomości mojego kraju i spisanie $w$ moim miasto czy $w$ moim regionie, ekonomiczne, biznesowe, klimat, pogoda, co się dzieje, chciatbym zawsze być na bieżąco

kod: atmosfera

Tabela 17

Narracja 17 W4, s. 1; W4, s. 2

Każdy kraj ma taki swój klimat, jakby taki swój uczucia. Tego, nawet możesz czuć od razu jak lądujesz w jakimś kraju, wychodzisz z samolotu i już czujesz, że to jest zupełnie inny niż swojego kraju

Narrator dostrzega istotność położenia geograficznego, klimatycznego i jego wpływów na charakter narodowości, na jej charakterystyczne emocje. Tak, to jest atmosfera, nie wiem to jest taka no, to się łaczy wszystko razem z np. z pogoda, z ludzi z wszystko z wyglądu w ogóle budynków, ulica, plaża, wszystko, nie? (Narrator pyta retorycznie) Wszystko to się czujesz, że Ty jesteś w jakimś miejscu a nie w innym, a może czasami są trochę podobne jakieś miejsca, sq̨ bardzo daleko masz tutaj taki klimat równikowy

kod: brak poczucia przynależności do kraju, brak patriotyzmu

\section{Tabela 18}

\section{Narracja 18 W1, s. 2; W1, s. 3}

Brazylia to duża część z Portugalia a Portugalia Hiszpania Włochy prawie to jest ta część ta sama, krajach śródziemny tam jest jedna kultura i nasz język pochodzi z łaciny, który się wiążę z francuski, włoski ta sama rodzina, my mamy rodzinę łacińska, a Portugalczycy, Portugalia Hiszpania to jest część Iberia, emigrowali tam, w nowym świat Brazylijczycy pomieszali się z Afrykańczycy z Indianie później z Arabowie z Turków. To wszystko buduje naszą tożsamość brazylijską. Narrator wskazuje z jednej strony na bogactwo tożsamości „misz-masz”, a z drugiej, na zagubienie Brazylijczyków. Trudno w takiej sytuacji określić, kim są.

Mój naród nie jest patriota, jesteśmy kombinowani z wielu narodowości tutaj jest otwarty kraj

kod: więź z Brazylią ze względu na klimat, specyfikę architektury

\section{Tabela 19}

Narracja 19 W4, s. 2.

Wygląd np. tak jak mówiłem architektura jest zupełnie inna niż np. niż $w$ Europie czy $w$ Polsce jest zrobiony bardziej dla dostosowania do klimatu: goracy, wilgotne, dużo pada i dużo słońce 
Narrator nie posiada identyfikacji państwowej, Jego autoidentyfikację można uznać za rozproszoną, rozmytą, zatartą.

Kategoria nadrzędna: identyfikacja narodowościowa; kategoria podrzędna: naród; kod: czynniki kształtujące naród

\section{Tabela 20}

Narracja 20 W3, s. 5

Elementy kształtujące naród: państwo, historia, język, klimat. Narrator dodaje, że jeszcze ważna jest komunikacja z innymi. Zdaje on sobie sprawę z ich istotności w kształtowaniu jego osobowości.

kod: związki małżeńskie

Tabela 21

Narracja 21 W3, s. 6

związki międzyetniczne, międzykulturowe

kod: międzykulturowość w Brazylii

\section{Tabela 22}

Narracja 22 W1, s. 7

Nigdy w Brazylii nie ma dzielnicy dla czarnych, dzielnicy dla białych, wszędzie sq i czarni i biali razem

kod: relacje interpersonalne między Brazylijczykami

\section{Tabela 23}

\section{Narracja 23 W4, s. 28}

To nie jest Europa uwierz mi, tam to jest kontakt Narrator mówi o relacjach z ludźmi, ale też o braku dystansu fizycznego. Można porozmawiać z nim tak jak znasz go dziesięć lat, nawet krzyczysz na niego (śmiech), on krzyczy dalej to znaczy, że kłócicie i jest dobrze...Narrator uważa, że wtedy, gdy są emocje jest życie. Tak krzyczq tam wiesz normalne. Krzycza, to nie znaczy, że jest źle to nie znaczy, że się kłócq, to znaczy, że jest dobrze. Jak się nie krzycza to wtedy, to jest niepokojace Narrator uważa, że brak emocji jest nienaturalny

Kategoria podrzędna: samookreślenie narodowościowe; kod: poczucie tożsamości narodowej

\section{Tabela 24}

\section{Narracja 24 W3, s. 2; W3, s. 3}

Obywatelem świata, a najbardziej czuję się obywatelem krajach południa .Ja mówi dużo, głośnie to znaczy nie teraz, ale na chwila spontaniczna widzi taki bez kontrola, widzi głos, taki nie wasz, taki głośny, macham rękami dużo, denerwuje się szybko, mogę rozmawiać z byle kim bez żadnego dystansu, poznam dużo ludzi, dużo pytań śmiało, które może tutaj w Polsce sq takie np. nie powinno pytać, dla mnie to nie ma problemu z tym. Dlatego czuje się bardziej takq osoba, może takq Trzeciego Świata, ale ja uważam, że to nic złego $w$ tym Trzeciego Świata, może nie sq rozwinięci za bardzo ekonomicznie, może nie sq cywilizowani, ale maja dobre cechy, sq bardziej naturalne. Narrator wyraża własną ekspresyjność dziecka, ufność dziecka, otwartość do rozmów i ciekawość świata.

\section{Tabela 25}

Narracja 25 W3, s. 4

(hm..)Tak, to jest bardzo ważne, ponieważ czujesz takim elementem, które po prostu nie wiem jak to powiedzieć po Polsku, ale spróbuję. Czuje, że wszystko jest normalność nie jest taki coś, które dziwne albo, które po prostu nie należysz do takich, chociaż fajny poznać, takich rzeczy, bo ja lubię poznawać nowy rzeczy, ale też za czasu będzie tęsknił za waszą tradycja, dlatego się czuję zgubiony. Narrator przejawia ciekawość świata, otwartość, chęć rozwoju, Mówi o poszukiwaniu własnej tożsamości.

kod: dystans do mężczyzn Polaków

\section{Tabela 26}

Wypowiedź narratora 26 W4, s. 15

Chodzę w jakimś tam miejsca, widzę Brazylijczyków i już mam znajomości nowe, ja nie obawiam tego, że jak ja pójdę do nich i porozmawiam oni mnie odrzucaja, ja tego nie boja. Ja żyje wśród pół mln ludzi tutaj w Poznaniu i widzę dużo, ale jakby czuję, że bardzo duży dystans między np. ja i tych facetów z Polski, ja nie mam żadnego kolegę z Polsk. Narrator jest w stanie charakterystycznym dla otwartości dziecka a Polacy funkcjonują w normach, zasadach, racjonalnie. Ma on inne wyobrażenie o relacjach, inaczej w nie wchodzi. Jest bardziej otwarty, ufny, ale też niedojrzały, jak dziecko.

kod: tradycja

\section{Tabela 27}

\section{Wypowiedź narratora 27 W3, s. 3}

Sa taki tradycja, albo taki dni, które specyficznie zrobimy, co niektóre, nie czuje się tutaj w Polsce, bo oni tutaj robią coś innego w ogóle i to właśnie wychodzi taka różnica, czuje, że nie należy stąd tylko należy do innego miejsca, bo tam się wychowałem, bo tam cały czas miałem tę tradycję. Narrator mówi o poczuciu odrębności, które traktuje jak „alibi”, by się nie zmieniać. Jest to spowodowane chęcią zachowania swojej odrębności i poczucia tożsamości - z jednej strony „ogląda się" w ludziach i szuka siebie, z drugiej odcina się od brania od ludzi lekcji, tym samym (na tym etapie swojego życia) ograniczając kształtowanie swojej tożsamości

kod: wydarzenia narodowe

\section{Tabela 28}

Wypowiedź narratora 28 W3, s. 6

Ta wydarzenia, które się dzieja, na co dzień to sq chyba najważniejsze w kraju

kod: ojczyzna

kod: znaczenie przynależności narodowościowej 


\section{Tabela 29}

Wypowiedź narratora 29 W3, s. 6

To jest miejsce, które na pewno zawsze możesz do niej wracać i czujesz w niej, mówiq, że wszędzie jest dobrze, ale najlepiej u siebie. To miejsce, gdzie nikt cię nie wygania, nikt cię nie deportuje, czujesz pełnym prawo, masz swojo prawo, nie musisz męczyć, bo tu jesteś obywatelem miejsca, i masz swoje prawu, tu jest miejsce, które zawsze Cię akceptuje Narrator opowiada o swoim świecie ukochanego dziecka, jakby żył w idylli.

kod: symbole narodowe

\section{Tabela 30}

\section{Wypowiedź narratora 30 W3, s. 12}

Historią na pewno znam, kultura na pewno znam, symboli narodowy też znam. Order i progresu, (chwila zastanowienia) Wszystko znam (śmiech), na pewno, bo to się rosne, bo to się wychowuję się $w$ tym

Narrator ma świadomość wpływu wychowania na znajomość symboli narodowych, potwierdza ich znajomość.

Identyfikacja narratora polega na tym, co badany mówi o sobie, o ludziach, o świecie brazylijskim, ale jeszcze sobie nie uświadamia swojej tożsamości. Odbywa się ona przez obcowania z Obcym - branie i nie branie od Niego - asymilowanie się i odcinanie. Jeśli narrator zaakceptuje różnorodność narodów, zaakceptuje różnorodność siebie samego.

\section{Wymiar europejski wielowymiarowej tożsamości badanego}

Kategoria nadrzędna: identyfikację europejską

Kategoria podrzędna: osobiste odczuwanie związku z Europą

kod: poczucie bycia Europejczykiem

\section{Tabela 31}

Wypowiedź narratora 31 W3, s. 12; W1, s. 2; W3, s. 2; W1, s. 2

Na pewno Europejczykiem, nie (śmiech). Trochę, ale nie dużo. Zna się kilka języków. Dobrze, czuję się bardziej na pewno nie Europejczyk. Na pewno np. jak bym rozmawiał z jakimś tam pochodzenie India, China, Afryka bym czuć cos nowego od niego, na pewno bym odkrywał jeszcze coś nowego od niego inne niż ja mam, np. jak bym rozmawiał z Meksykaninem, Kolumbijczykiem, Argentyno, Hiszpanem, Portugalczyk, bym czuł takie podobieństwa, bardziej niż rozmawiam z kimś z Niemiec, Norwegii, Polaki z Rosji

Narrator wyraża emocje, są one jego drogowskazem, intuicją emocjonalną, jak rozmawiać z ludźmi różnych narodowości. Jest to zasób narratora, zasób dziecka do rozwoju.

kod: wiedza o krajach europejskich
Tabela 32

Narracja 32 W1, s. 4; W1, s. 3

Tak posiadam wiedzę o różnych krajach o Polsce, o Hiszpanii. Chciałbym mieszkać w Polsce

Narrator chce mieszkać w Polsce, ponieważ zachwyca się rozwojem cywilizacji.

kod: więź z europejskością

\section{Tabela 33}

Narracja 33 W1, s. 5

Jest to cześć mojego życia; już jak spotkam takie coś to nie jest dla mnie dziwne, już umiem jakoś to prowadzić; czuję, że mam więcej możliwości tutaj. Narrator chce własnego rozwoju. Chciałbym używać mój inność $w$ Polsce tutaj, bo wiem jakbym nie zrobił dużego błędu pół roku temu to bym miał, będę miał dobra przyszłość tutaj, mimo, że Polscy narzekają, że oni tutaj maja kraj, który jest biedny, ja nie widzę tej biede; jak ja chodzę po ulicach brazylijskich, ja widzę biedę, tutaj nigdy nie widziałem biedy. Tutaj ulice sq piękne, czyste, każda dzielnica prawie jest dobrze zorganizowana. U nas sq fawele (dzielnice nędzy na obrzeżach bogatych miast)

Narrator posiada umiejętność docenienia, radości z tego, co jest, ale również ma percepcję biedy - on widzi biedę emocjonalną przy jego bogactwie emocjonalnym. Jednocześnie zachwyca się bogactwem materialnym, którego nie ma.

kod: potrzeba szacunku

\section{Tabela 34}

Narracja 34 W3, s. 4

Spędząc tutaj 5 lat, będę tęsknił za Polską. Sa rzeczy, które mi się bardzo podobaja i na pewno będq mi brakować i dlatego mam świadomość, że ta osoby będą nam bardziej szanować jak będziemy zachować w ich kultura, albo tak jak oni zachowuja, fajnie by było czasami tak sam to zrobić, bo już mieszkasz kilka lat i wiesz, o co chodzi

kod: smutek

\section{Tabela 35}

\section{Narracja 35 W3, s. 4}

Mogę nie należeć (mogę nie mieć poczucia przynależności narodowościowej, to narratorowi nie przeszkadza) $n p$. w ogóle do Polski, ale mogę żyć normalnie w Polsce i szczęśliwe, nie moga być takie duże przeszkód, że ja nie należę do tej miejsca, do tej kultury, albo coś takiego to nie znaczy, że ja nie mogę zamieszkać, ponieważ, możemy się nauczyć coś nowego, dopasować, może nawet później zachować troszkę podobnie

Narrator ma świadomość, że adaptowalność to cecha rozwoju. Zdaje on sobie sprawę, że należy mieć te umiejętności, aby rozwijać się dalej.

kod: rozwój osobowości, zmiana osobowości 


\section{Tabela 36}

Narracja 36 W3, s. 4; W3, s. 5; W3, s. 7

Dużo się zmieniło, na bardzo dobra, tak $w$ ogóle moja zamieszkania $w$ Polsce to jest duża plus, mimo, że teraz pojawiała nie fajne czasy, ale myśle, że to bardzo dobra nauka dla mnie, Zrozumiałem dużo rzeczy. Tu jest dobrze, nie bardzo dobrze, ani nie jest źle, widzę negatywne rzeczy, widzę pozytywne bardziej niż negatywne i dziwi mi się, że to sq wszyscy tech krajów, które mówiq po wieluch języków i mogli się jakoś się dogadać

kod: wiedza o Polsce

\section{Tabela 38}

Narracja 37 W3, s. 12

Ja nie chodziłem tu do podstawówki, gimnazjum, liceum i na pewno $w$ takim etapu życiowym $w$ tym szkole uczy się dużo, historii, geografii, tych krajów i dlatego mi brakowało i nie mam tyle czasu żebym przeczytał tyle książki o Polski żebym wiedział miej więcej, o co tam chodzi, ale dużo wiem, np. wiem, że Gniezno było pierwsza stolica Polski, później Kraków, przeniosła się do Warszawy, wiem mniej więcej troszkę o Polsce

kod: więź z wytworami kultury europejskiej (odniesienie do Polski)

\section{Tabela 38}

Narracja 38 W4, s. 2

$W$ innym np. miastu świata to sa $w$ ogóle maja deptak $w$ centrum, może centrum, jest zupełnie inaczej. W Polsce zawsze mi się kojarzy jakimś tam, tutaj sa osiedla, jak się zbliżymy to sq już kamienice. I tu jest jakiś rynek i czuć tak jakby w Polsce, dla mnie to jest wygląd, Polska dla mnie

kod: identyfikacja z wytworami kultury europejskiej/ambiwalencja

\section{Tabela 39}

Narracja 39 W4, s. 3

Mimo, że sa perfekcyjne, ale jakoś taki nie czuje, że należy do tego, nie? Fajnie no, chodzę tak no fajne chodzę po Galerii coś tam. Nawet jak byłem $w$ Niemczech jest bardziej rozwinięte niż Polska, technologia bardzo mi się podoba, ale jakoś wola bardziej moja taki wiesz no, taki palma, taki domy nie sa dokładne, taki identyczne. Czy mi się wydaje, tutaj wszystko jest takie identyczne bardziej?

Narrator mówi o emocjach, które wzbudza w nim architektura

kod: przepisy prawne dotyczące studentów obcokrajowców

\section{Tabela 40}

\section{Narracja 40 W4, s. 8}

$W$ Polsce powoli tych praw się dostrzegają. Jak ja przyjechałem do Polski nie było studentom prawo pracować, dopiero w zeszłym roku, w Niemczech od 10 lat studenci maja prawo. Oczywiście ograniczona liczba godzin, tylko $w$ zeszłym roku tutaj dodali ten prawo jakoś poprawili, a po co mi teraz jak nie moge z nich korzystać? Jak przyjechałem do Polski chciałem pracować
Narrator mówi o poczuciu ograniczonych możliwości pracy, rozwoju

kod: brak pomocy i zrozumienia dla obcokrajowców

\section{Tabela 41}

Narracja 41 W4, s. 8

Nie ma pomoc, jest prawo, nie ma zrozumienia (narrator nie rozumie) i to mi się nie podoba $w$ Polsce, że traktuja nas tak jakby nie wiem co, przyjdziesz do studia coś takiego studiowałeś to już koniec, idź

Narrator mówi o lekceważeniu, braku troski.

\section{Tabela 42}

Narracja 42 W4, s. 8

Ja mam znajomych, studiuja $w$ Niemczech, Francji maja inne możliwości i nie jest tak, że kończysz studia i wracaj

kod: obcość, inność

\section{Tabela 43}

\section{Narracja 43 W4, s. 15}

Przyjaźń, miłość sa bezcenne, ale sa bardzo mało. Narrator mówi o najważniejszych wartościach, podkreśla, że są rzadkim dobrem. Ciężko spędzimy całe życie, aż znajdziemy, a nie zawsze człowiek szuka, sam nie żyje zawsze. Narrator mówi o potrzebie bliskości, połączenia z kimś) Nawet jak wie, że nie ma przyjaciół i tak potrzebuje jaką́ osoby, może Pani zauważy, że zawsze ludzie z tego samego kraju albo z regionu sq razem. Zobaczmy obcokrajowcy w Polsce np. Hindusi znajdziesz z Hindusami, Turków z Turkami, a murzynów ja zauważyłem jak chodziłem na imprezę, że zawsze są razem, nie sq mieszane. Tożsamość ułatwia kontakty miedzy ludźmi, czujesz się bliski tej osoby

Narrator nadaje specyficzne znaczenie poczuciu tożsamości europejskiej. Wyraża to w mówieniu o solidarności kulturowej, przy jednoczesnej świadomości zróżnicowania kulturowego.

\section{Realizacja edukacji międzykulturowej w kontekście badanego przypadku - wybrane refleksje autorek}

W trakcie wielokrotnego namysłu autorek artykułu nad badanym przypadkiem pojawiają się pytania dotyczące realizacji edukacji międzykulturowej: Czy treści kształcenia międzykulturowego są jednakowe na wszystkich kierunkach studiów? Jak przebiegała współpraca z administracją uczelni, na której studiował narrator? Co przyczyniło się do jego problemów w Polsce? (poszukiwanie własnej tożsamości, brak świadomości prawnej, brak realizacji programów edukacji międzykulturowej). Dlaczego, mimo otwartości, inteligencji emocjonalnej badany nie miał polskich kolegów, przyjaciół (tylko koleżanki)?

Treści kształcenia międzykulturowego powinny być jednakowe na wszystkich kierunkach studiów (nie ma spójności i jednolitości w tej kwestii). Jednak bez względu na sposoby realizacji i rodzaje programów edukacji międzykulturowej narrator mówi głównie o ideałach dziecka: jak to będzie w Polsce, mówi o chęci wyjazdu w świat bez świadomości, że ma się w świecie zaadaptować i dostosować do panujących 
reguł w tym świecie. Brak polskich kolegów i przyjaciół u narratora jest prawdopodobnie uwarunkowany indywidualnie. Do powstania trudnej sytuacji badanego w Polsce prawdopodobnie przyczyniła się zarówno niewielka współpraca z administracją uczelni jak i jego dziecięcość (przewaga emocji nad racjonalnością, ekspresyjność i ufność dziecka) a także brak wsparcia rodziny (ze względu na odległość). Narrator nie wspomina o programach edukacji międzykulturowej, ma żal o nieuświadomienie prawne.

\section{Wnioski}

1. Przypadek posiada walory poznawcze: duża wiedza o świecie, inteligencja; doświadczanie smutku i tęsknoty; świadomość, że w chwili powrotu do Brazylii pojawi się tęsknota za Polską, za Europą.

- Inteligencja, duża intuicja emocjonalna, wykształcenie, nie chronią narratora przed deportacją do Brazylii.

- Narrator ma trudność z poczuciem własnej tożsamości. Jest zdolnym, młodym człowiekiem, mającym duży potencjał do rozwoju, ale cały czas poszukuje punktów odniesienia kształtujących jego tożsamość.

2. Przypadek posiada walory praktyczne: istnieje nieustanna potrzeba podejmowania realizacji programów edukacji międzykulturowej wobec studentów, którzy chcą kontynuować kształcenie w Polsce a znajdują się w podobnej, trudnej sytuacji życiowej.

3. Istnieje małe prawdopodobieństwo powrotu badanego do Polski, ale duże do innego kraju europejskiego.

\section{Dyskusja}

Nie ulega wątpliwości, że pojęcie tożsamość podlega refleksji, metafizycznej analizie (Skarga, 1997) a także występuje w wielu wymiarach i ekspresjach (Borowik, Leszczyńska, 2007). Natomiast kształtowanie tożsamość człowieka jest procesem złożonym, wymagającym ustawicznego definiowania, integracji lub reintegracji
(Nikitorowicz, 2015), z jednoczesną możliwością konfliktów i zaburzeń poczucia tożsamości (Sokolik, 1992), dysfunkcjami tożsamości (Kubacka-Jasiecka, Kuleta, 2008) z trajektorią oraz niepokojami tożsamościowymi (Giddens, 2001). Jak podkreśla J. Nikitorowicz (2015, s. 125) wielość zjawisk i procesów współczesnego świata wymusza autoidentyfikację. Potwierdzaja to wyniki przedstawionego badania metodą jakościowego studium przypadku. Jednocześnie kreowanie toźsamości kulturowej traktowane jest jako wyzwanie XXI (Suchocka, Królikowska, 2014). Stało się to szczególnie istotne w odniesieniu do młodego człowieka pochodzenia brazylijskiego, poszukującego poczucia tożsamości.

Zastosowana w przedstawionym raporcie Teoria Zachowań Tożsamościowych (Ogrodzka-Mazur, 2014, s. 28) ma szerokie zastosowanie dla badań międzykulturowych. Istnieje wiele takich badań, gdzie zastosowano tę teorię m.in. do konstruowania metodologii badań oraz interpretacji uzyskanych wyników (Gajdzica, 2013; Grabowska, 2013; Kurzępa, 2007; Misiejuk, 2013; Ogrodzka-Mazur, 2007; Sobecki, 2007; Szczurek-Boruta, 2007; Urlińska; Wojakowski, 2007) (Ogrodzka-Mazur, 2014, s. 28).

Już w 1966r. Aron Gurwitsch przeprowadził badania fenomenologiczne dotyczące tożsamości i czasowości (Moustakas, 2001) mające charakter jakościowy. Natomiast profile identyfikacyjne (podobnie jak w przedstawionym badaniu) uczniów szkół z polskim językiem nauczania na Białorusi, Ukrainie i w Czechach zaprezentowała Barbara Grabowska stosując strategię ilościową z metodą sondażu diagnostycznego i techniką ankiety.

Analiza stanu badań dotyczących kategorii tożsamości przekracza ramy tego opracowania, ale raport z jakościowego studium przypadku wpisuje się i potwierdza dylematy, niepokoje tożsamościowe oraz silną potrzebę autoidentyfikacji. W trakcie badań, zgodnie z założeniami badań jakościowych (Flick, 2012, s. 14) została wypracowana następująca hipoteza: Tożsamość narratora nie została jeszcze skrystalizowana. Poszukuje on tożsamości, określa się multikulturowo, dlatego chce dostosować się do krajów, w których przebywa.

\section{Literatura:}

1. Bąk, S. (2015). Brazylia jest jedynym brazylijskim krajem na całym świecie. Brazylijskim aż do przesady. Pobrane z: http://educover.pl/czasopismo/brazylia-jedynym-brazylijskim-krajem-calym-swiecie-brazylijskim-az-przesady/

2. Bokajło, W. (2009). Europa i europejskość: idee i pojęcia. W: W. Bokajło, A. Pacześniak (red.), Podstawy europeistyki. Podręcznik akademicki (s. 28). Wrocław: Alta 2.

3. Borowik, I., Leszczyńska, K. (2007). Wokół tożsamości: teorii, wymiary, ekspresje. Kraków: Zakład Wydawniczy „Nomos”.

4. Boski, P. (2010). Kulturowe ramy zachowań społecznych. Warszawa: Wydawnictwo Naukowe PWN, Akademica Wydawnictwo SWPS.

5. Chase, S. E. (2009). (tłum. F. Smith). Wywiad narracyjny. Wielość perspektyw, podejść, głosów. W: N.K. Denzin, Y.S. Lincoln (red.), Metody badań jakościowych tom 2, (s. 15-55). Warszawa: Wydawnictwo Naukowe PWN.

6. Flick, U. (2012). Projektowanie badania jakościowego. Warszawa: Wydawnictwo Naukowe PWN.

7. Flyvbejerg, B. (2005). Pięć mitów o badaniach typu studium przypadku. Studia socjologiczne, 2(177), 41-69.

8. Gajda, J. (2003). Europejskość i polskość jako kategoria wspólnotowych wartości transmisji dziedzictwa kulturowego jednoczacej się Europy. Chowanna, 1, 38-49.

9. Giddens, A. (2001). Nowoczesność i tożsamość. Ja i społeczeństwo w epoce późnej nowoczesności. Warszawa: Wydawnictwo Naukowe PWN. 
10. Grabowska, B. (2012). Profile identyfikacyjne uczniów ze szkół z polskim językiem nauczania na Białorusi, Ukrainie i w Czechach. Studia Migracyjne - Przegląd Polonijny, 84(4), 39-56.

11. Grey, R.M. (2005). Archetypal Explorations: An Integrative Approach to the Human Behavior. London; New York: Routledge, cyt. za: Gwiazda, A. (2010). Zarządzanie jako nauka wieloparadygmatowa. Współczesne Zarządzanie, 4, 22-23.

12. Hałas, E. (1983). Floriana Znanieckiego definicja sytuacji a interpretacyjny paradygmat socjologii. Studia Socjologiczne, 1(88), 35.

13. Jacob, G. (2001). Wywiad narracyjny w badaniach biograficznych. W: D. Urbaniak-Zając, J. Piekarski (red.), Jakościowe orientacje w badaniach pedagogicznych (s. 111-126). Łódź: Wydawnictwo UŁ.

14. Jeznach, A. (2011). Tożsamość transkulturowa: rzeczywistość czy ideał? Warszawa: Bellona.

15. Jeznach, A. (2016). Tożsamość kulturowa dziecka. W: D. Waloszek (red.), Encyklopedia Dzieciństwa. Antropologiczno-kulturowy konstrukt dzieciństwa. Pobrane z: www.encyklopediadziecinstwa.pl

16. Kubacka-Jasiecka, D., Kuleta, M. (red.). (2008). W kręgu psychologicznej problematyki tożsamości. Kraków: Wydawnictwo Uniwersytetu Jagiellońskiego.

17. Kvale, S. (2012). (tłum. A. Dziuban). Prowadzenie wywiadów. Warszawa: Wydawnictwo Naukowe PWN.

18. Leszczak, O. (2009). Metodologiczne Rozważania na temat Europejskości i problem Etnosu, Narodowość-Superetnos-Hiperetnos. W: Europa homogeniczna czy komplementarna - recepta na zjednoczenie (s. 281300). The Peculiarity of Man, Toruń-Kielce, Pobrane z: www.ujk.edu.pl/ leszczak/peculiarity\%208.doc

19. Lewowicki, T. (1995). O badaniach społeczności pogranicza-od parcjalnych opisów ku elementom Teorii Zachowań Tożsamościowych. W: J. Nikitorowicz (red.), Edukacja międzykulturowa. W kręgu potrzeb, oczekiwań i stereotypów (s. 13-27). Białystok: Trans-Humana.

20. Lewowicki, T. (2010). Socjologizm vs pedagogizm - czy synteza w edukacji międzykulturowej? W: T. Lewowicki, E. Ogrodzka-Mazur (red.), Edukacja międzykulturowa- teorie, poglądy, doświadczenia społeczne. (s. 492-493). Cieszyn-Warszawa-Toruń: Wydział Etnologii i Nauk o Edukacji Uniwersytetu Śląskiego, Wydawnictwo Adam Marszałek, Wyższa Szkoła Pedagogiczna ZNP w Warszawie.

21. Łuszczak, W. (2011). Normatywny i interpretacyjny paradygmat w badaniach pedagogicznych. Sosnowiec: Wyższa Szkoła Humanitas, Oficyna Wydawnicza „Humanitas”. Pobrane z: oai:www.sbc.org.pl:22112

22. Malim, T., Birch, A., Wadeley, A. (1994). Wprowadzenie do psychologii. Warszawa: Wydawnictwo Naukowe PWN.

23. Malinowski, M. (2008). Smutek i serdeczność: brazylijski charakter narodowy a blizny epoki kolonialnej. Warszawa: Ameryka Łacińska, CESLA UW.

24. Malinowski, M. (2011). W poszukiwaniu brazylijskości. Warszawa: CESLA UW.

25. Malinowski, M. (2013). Brazylia. Republika. Dzieje Brazylii w latach 1889-2010. Warszawa: Muzeum Historii Polskiego Ruchu Ludowego, Instytut Studiów Iberyjskich i Iberoamerykańskich UW.

26. Moustakas, C. (2001). Fenomenologiczne metody badań. Białystok: Trans-Humana.

27. Nikitorowicz, J. (2003). Wartości etosu jako podstawa kształtowania tożsamości wielokulturowej, podłoże konfliktów kulturowych i cel edukacji międzykulturowej. W: T. Lewowicki, E. Ogrodzka-Mazur, A. Gajdzica (red.), Świat wartości i edukacja międzykulturowa (s. 9-36). Cieszyn-Warszawa: Uniwersytet Śląski-Filia w Cieszynie. Wyższa Szkoła Pedagogiczna ZNP w Warszawie.

28. Nikitorowicz, J. (2007). Kreowanie toźsamości dziecka. Interdyscyplinarna seria akademicka: edukacja międzykulturowa. Gdańsk: GWP.

29. Nikitorowicz, J. (2015). Model kształtowania się tożsamości kulturowej w warunkach wielokulturowości. Psychologia Wychowawcza, 7, 125-134.

30. Nikitorowicz, J. (red.). (1995). Edukacja międzykulturowa. W kręgu potrzeb, oczekiwań i stereotypów. Białystok: Wyd. Trans-Humana.

31. Ogrodzka-Mazur, E. (2014). Cieszyńska Szkoła badań pogranicza Profesora Tadeusza Lewowickiego. Pedagogika Przedszkolna i Wczesnoszkolna, 2(2), 25-39.

32. Phinney, J. (1992). The Multigroup Ethnie Identity Measure: A new scale for use which adolescent and young adults from diverse groups. Journal of Adolescent Research, 7, 156-176.

33. Schütz, A. (1984). Potoczna i naukowa interpretacja ludzkiego działania. W: E. Mądrzycki, Kryzys i schizma. Antyscjentystyczne tendencje w socjologii współczesnej (s. 137-191). Warszawa: PIW.

34. Schütz, A. (2008), Dokonywanie wyboru projektu działania, W: O wielości światów. (s. 131-152). Kraków: NOMOS.

35. Sokolik, M. (1992). Psychoanaliza i Ja. Kliniczna analiza poczucia toźsamości. Warszawa: Jacek Santorski \&Agencja Wydawnicza.

36. Stake, R. (2009). Jakościowe studium przypadku. W: N.K. Denzin, Y. Denzin (red.), Metody badań jakościowych. tom I, (s. 623-654). Warszawa: PWN.

37. Suchocka, A., Królikowska, I. (2014). Kreowanie tożsamości kulturowej jako wyzwanie XXI wieku. Colloquium Wydziału Nauk Humanistycznych i Społecznych. Kwartalnik, 4, 73-88.

38. Szachaj, A. (2014). O interpretacji. Kraków: Universitas.

39. Yin, R.K. (tłum. J. Gilewicz). (2015). Studium przypadku w badaniach naukowych. Projektowanie i metody. Kraków: Wydawnictwo Uniwersytetu Jagiellońskiego. 